\title{
Subclinical hypothyroidism: Is it important in intracytoplasmic sperm injection cycles?
}

\section{Subklinik hipotiroidi: İntrasitoplazmik sperm enjeksiyonu siklusları için önemli mi?}

\author{
Eray Çalışkan ${ }^{1}$, Rahime Nida Ergin ${ }^{1}$, Deniz Can Öztekin², Bülent Kars³ ${ }^{3}$ Seda Çakır ${ }^{4}$, Kenan Sofuoğlu \\ ${ }^{1}$ Bahçeşehir University Faculty of Medicine, Department of Obstetrics and Gynecology, İstanbul, Turkey \\ ${ }^{2}$ Ege Maternity and Gynecology Training and Research Hospital, Clinic of Obstetrics and Gynecology, İzmir, Turkey \\ ${ }^{3}$ University of Health Sciences, Kartal Dr. Lütfi Kırdar Training and Research Hospital, Clinic of Obstetrics and Gynecology, İstanbul, Turkey \\ ${ }^{4}$ University of Health Sciences, Zeynep Kamil Maternity and Children's Health Training and Research Hospital, Clinic of Obstetrics and \\ Gynecology, İstanbul, Turkey
}

\begin{abstract}
Objective: To compare intracytoplasmic sperm injection (ICSI) outcomes of women with subclinical hypothyroidism with those of euthyroid women. Materials and Methods: A retrospective case-control study was conducted. Out of 2529 ICSI cycles evaluated, 41 women with hypothyroidism, 28 women with hyperthyroidism, and 128 women with subclinical hyperthyroidism were excluded, and 2336 cycles were analyzed. Women were identified as having subclinical hypothyroidism (case group, $\mathrm{n}=105$ ) in the presence of a thyroid-stimulating hormone level $>4.5 \mathrm{mU} / \mathrm{L}$ and normal free $\mathrm{T} 4$ and compared with euthyroid controls ( $\mathrm{n}=2231$ ).

Results: The mean age, body mass index, day 3 follicle-stimulating hormone level, and antral follicle count of the study patients were similar to the control group ( $\mathrm{p}>0.5)$. The cycle cancellation rate of the study group was similar to the control group $(13.3 \%$ vs. $7.6 \%, p=0.1)$. The clinical pregnancy rate was $21.2 \%$ in the study group, which was significantly lower than the $35.8 \%$ in the control group $(\mathrm{p}=0.04)$. The take-home baby rate was also significantly lower in the study group compared with the control groups ( $13.5 \%$ vs. $31.4 \%$ respectively, $\mathrm{p}=0.01$ ).

Conclusion: Both the clinical pregnancy rate and the take-home baby rate is lower in women with subclinical hypothyroidism at the time of ICSI cycle. Keywords: Female, infertility, intracytoplasmic sperm injection, subclinical hypothyroidism, pregnancy rate
\end{abstract}

$\ddot{O} z$

Amaç: İntrasitoplazmik sperm enjeksiyonu (ICSI) uygulaması sonuçlarının, uygulanan subklinik hipotiroidi bulunan kadınlar ile ötiroid olan olgularda karşılaştırılmasıdır.

Gereç ve Yöntemler: Retrospektif olgu-kontrol çalışması olarak araştırıldı. Uygulanan 2529 ICSI siklusu içinden hipotiroidisi olan 41 kadın, hipertiroidisi olan 28 kadın ve subklinik hipertiroidisi olan 128 kadın dışlandı, sonuçta 2336 siklus değerlendirildi. Tiroid stimüle edici hormon düzeyi >4,5 mU/L ve serbest T4 düzeyi normal olan kadınlar subklinik hipotiroidi (olgu grubu, n=105) olarak değerlendirildi ve ötiroid kadınlar (kontrol grubu, n=2231) ile karşılaştırıldı.

Bulgular: Subklinik hipotiroidi olgularının ortalama yaş, vücut-kitle indeksi ve 3. gün folikül uyarıcı hormon değerleri kontrol grubu ile benzerdi $(\mathrm{p}>0,5)$. Siklus iptal oranları da istatistiksel olarak benzerdi $(\% 13,3$ 'e \% 7,6, p=0,1). Subklinik hipotiroidi olgularında kontrol grubuna göre klinik gebelik oranı istatistiksel anlamlı olarak daha düşüktü (olgu grubu \%21,2 ve kontrollerde \%35,8 p=0,04). Sağlıklı bebek doğum oranı da subklinik hipotiroidi olgularında kontrol grubuna göre istatistiksel anlamlı olarak daha düşüktü (sırasıyla \%13,5’e \%31,4, p=0,01).

Sonuç: Hem klinik gebelik oranı hem de sağlıklı bebek doğum oranı ICSI uygulanan subklinik hipotiroidi kadınlarda daha düşük olarak saptanmıştır. Anahtar Kelimeler: Kadın, infertilite, intrasitoplazmik sperm enjeksiyonu, subklinik hipotiroidi, gebelik oranı

Address for Correspondence/Yazışma Adresi: Rahime Nida Ergin, MD,

Bahçeșehir University Faculty of Medicine, Department of Obstetrics and Gynecology, İstanbul, Turkey

Phone: +90 5053737133 E-mail: drnidaergin@gmail.com

Received/Geliș Tarihi: 10.01.2017 Accepted/Kabul Tarihi: 11.05.2017

${ }^{\oplus}$ Copyright 2017 by Turkish Society of Obstetrics and Gynecology

Turkish Journal of Obstetrics and Gynecology published by Galenos Publishing House. 
PRECIS: In this multi-centered retrospective case-control study, we aimed to determine intracytoplasmic sperm injection (ICSI) outcomes of infertile women with subclinical hypothyroidism versus euthyroid infertile women, including higher numbers of ICSI cycles.

\section{Introduction}

Various experimental cell culture studies involving human and some animal species have shown that thyroid hormones have, to some degree, a stimulatory effect on granulosa and/or thecal cells ${ }^{(1-3)}$. Therefore, it is anticipated that disturbances in this thyroid-ovarian interaction might exert a negative influence on pregnancy as previously shown ${ }^{(4,5)}$. In this manner, hypoor hyper-thyroidism have their own ways of management; however, it is not clear for subclinical hypothyroidism, which is defined as a serum thyroid-stimulating hormone (TSH) above the defined upper limit of the reference range, with a serum free thyroxine (fT4) within the reference range ${ }^{(6)}$. It is rather a laboratory diagnosis because patients with subclinical hypothyroidism have no or fewer symptoms ${ }^{(6)}$. The routine serum assays used to rule out subclinical hypothyroidism are not recommended, except in some specific patient groups including pregnant women due to possible developmental problems of the fetus related to maternal high TSH levels ${ }^{(6)}$. However, a recent Cochrane database systemic review concluded that there was insufficient evidence to recommend the use of one intervention for clinical or subclinical hypothyroidism before or during pregnancy over another, for improving maternal, fetal, neonatal, and childhood outcomes ${ }^{(7)}$.

In a recent study of limited numbers of pregnant women with subclinical hypothyroidism, T4 treatment was reported to result in similar clinical pregnancy rates per cycle but higher embryo implantation rates, live birth rates, and lower miscarriage rates compared with the no treatment group ${ }^{(8)}$. In contrast with this study, subclinical hypothyroidism and overt hypothyroidism was shown not to benefit from T4 treatment in terms of the clinical pregnancy rates per started cycle, implantation rates, and the live birth rates per started cycle compared with euthyroid $\operatorname{controls}^{(9)}$. Therefore, in this multi-centered retrospective casecontrol study, we aimed to determine intracytoplasmic sperm injection (ICSI) outcomes of infertile women with subclinical hypothyroidism versus euthyroid infertile women, including higher numbers of ICSI cycles.

\section{Materials and Methods}

Hospital records of infertile women who attended participant referral study centers of assisted reproduction therapy (ART) between 2014 and 2015 were analyzed retrospectively in this retrospective case-control study. Patients without laboratory studies of thyroid functions, those with missing data related to ART, and those with thyroid function abnormalities such as thyroid autoimmunity diseases other than subclinical hypothyroidism were not included in the study. Ovarian stimulations were performed using a combination of gonadotropin-releasing hormone agonist/antagonist and follicle-stimulating hormone (FSH)/human menopausal gonadotropin. When the leading follicle diameter was larger than $17 \mathrm{~mm}$, human chorionic gonadotropin (hCG) was given. Oocytes were retrieved $35 \mathrm{~h}$ after hCG administration. Following oocyte preparation, insemination was performed using ICSI in all cases one hour later. After insemination, eggs were individually cultured until day 5 for blastocyst transfer. Data related to ICSI cycles, patients' demographics, laboratory results, and pregnancy outcomes were compared between the two groups of infertile women; the study group included infertile women with subclinical hypothyroidism and the control group comprised women who were euthyroid. Women were identified as having subclinical hypothyroidism in the presence of a TSH level $>4.5 \mathrm{mU} / \mathrm{L}$ and a serum fT4 within the reference range ${ }^{(6)}$. The patients with hyperprolactinemia had been treated with levothyroxine. Hyperprolactinemia is also common in subclinical hypothyroidism ${ }^{(10)}$; therefore, patients with both subclinical hypothyroidism and hyperprolactinemia were included in the study and were treated with levothyroxine and a dopamine agonist.

\section{Statistical Analysis}

Out of 2529 ICSI cycles with eligible data, 41 women with hypothyroidism, 28 women with hyperthyroidism, and 128 women with subclinical hyperthyroidism were excluded, and 2336 cycles were analyzed. The related statistical comparisons of groups were performed using the with ANOVA test and chi-square test, where appropriate. Correlation analyses were performed with Pearson's correlation. Statistical analyses were performed using SPSS statistics software (SPSS Statistics for Windows, version 17.0; SPSS Inc., Chicago, USA). The p value was set as $<0.05$ for significance.

\section{Results}

Of the included 2336 cycles, 105 women were identified as having subclinical hypothyroidism (study group) and 2231 women were included in the euthyroid control group. The mean age, body mass index, type and duration of infertility were similar between the groups; only causes of infertility differed between the groups (Table 1). Both the study group and control euthyroid group were statistically indifferent considering infertility analysis values including FSH, luteinizing hormone (LH), estrogen, total antral follicle count, and sperm analyses (Table 2). Of the cases with subclinical hypothyroidism, $46 \%$ $(\mathrm{n}=48)$ had associated hyperprolactinemia. The rate of patients with TSH values equal or higher than 10 was $11 \%(n=12)$. With the exceptions of significantly lower estradiol measurements and endometrial thickness on hCG day, the outcomes of controlled ovarian hyper-stimulation and ICSI of the study group were 
Table 1. Demographics of the study population and causes of infertility

\begin{tabular}{|llll}
\hline Variable & $\begin{array}{l}\text { Subclinical } \\
\text { hypothyroidism } \\
(\mathrm{n}=105)\end{array}$ & $\begin{array}{l}\text { Euthyroid } \\
\text { controls } \\
(\mathrm{n}=2231)\end{array}$ & $\mathrm{p}$ \\
\hline Age & $31.2 \pm 5.9$ & $32.1 \pm 5.2$ & 0.1 \\
\hline Body mass index & $24.1 \pm 3$ & $24.4 \pm 3.5$ & 0.4 \\
\hline Duration of infertility & $94.7 \pm 52.5$ & $102.2 \pm 59.7$ & 0.2 \\
\hline Secondary infertility & $15(14.3)$ & $449(20.1)$ & 0.6 \\
\hline Cause of infertility & & & \\
\hline Tubal factor & $20(19 \%)$ & $565(25.3 \%)$ & 0.1 \\
\hline Endometriosis & $3(2.8 \%)$ & $276(12.3 \%)$ & $0.003^{*}$ \\
\hline Anovulatory cycles & $5(4.7 \%)$ & $569(25.5 \%)$ & $<0.001^{*}$ \\
\hline Male factor & $40(38 \%)$ & $683(30.6 \%)$ & 0.1 \\
\hline Unexplained & $37(35.2 \%)$ & $138(6.1 \%)$ & $<0.001^{*}$ \\
\hline
\end{tabular}

*Statistically significant $(\mathrm{p}<0.05)$, chi-square test similar to those of the control group (Table 3). The cycle cancellation rate of the study group was similar to the control group ( $13.3 \%$ vs. $7.6 \%, \mathrm{p}=0.1$ ). The clinical pregnancy rate was $21.2 \%$ in the case group, which was significantly lower than the $35.8 \%$ in the control group $(\mathrm{p}=0.04)$. The take-home baby rate was also significantly lower in the study group compared with the control group ( $13.5 \%$ vs. $31.4 \%$, respectively; $\mathrm{p}=0.01$ ) (Table 4). Miscarriage rates were also higher in the study group compared with the control group (36\% vs. $24 \%$ ); however, the result was not statistically significant.

When the outcomes of patients with subclinical hypothyroid with and without hyperprolactinemia were compared in terms ICSI cycle parameters and pregnancy outcomes, none was found as significantly different (Table 5). In the subgroup analysis of patients with subclinical hypothyroidism according to TSH level $(<10$ versus TSH $\geq 10)$ for the outcomes of ICSI and pregnancy outcomes, only significantly lower levels of estradiol on hCG day and a significantly higher rate of cycle cancellation were present in patients with TSH $\geq 10$ (Table 6).

Table 2. Laboratory analyses of the women and men

$\begin{array}{llll}\text { Laboratory analysis } & \text { Subclinical hypothyroidism }(\mathrm{n}=105) & \text { Euthyroid controls }(\mathrm{n}=2231) & \mathrm{p} \\ \text { FSH } & 7.6 \pm 2.5 & 7.1 \pm 2.7 & 0.1 \\ \text { LH } & 4.9 \pm 2.3 & 5.1 \pm 2.7 & 0.4 \\ \text { E2 } & 44.2 \pm 22.9 & 45.7 \pm 30.1 & 0.6 \\ \text { Total antral follicle count } & 12.8 \pm 6.5 & 13.1 \pm 5.8 & 0.6 \\ \text { Total motile sperm count } & 51.1 \pm 23.7 \times 10^{6} & 47.8 \pm 20.4 \times 10^{6} & 0.1 \\ \text { Oligospermia }(<20 \times 10 \% \mathrm{~mL}) & 10(9.5 \%) & 246(11 \%) & 0.6 \\ \text { Oligoasthenoteratospermia } & 31(29.5 \%) & 495(22.1 \%) & 0.07 \\ \text { Azoospermia } & 9(8.5 \%) & 188(8.4 \%) & 0.9\end{array}$

*Statistically significant $(\mathrm{p}<0.05)$, independent samples t-test

FSH: Follicle-stimulating hormone, LH: Luteinizing hormone, E2: Estradiol

Table 3. Outcome of controlled ovarian hyperstimulation and intracytoplasmic sperm injection

\begin{tabular}{llll}
\hline Outcome & Subclinical hypothyroidism $(\mathrm{n}=105)$ & Euthyroid controls $(\mathrm{n}=2231)$ & $\mathrm{p}$ \\
\hline Total FSH used & $3003 \pm 1357$ & $3154 \pm 1338$ & 0.2 \\
\hline Antagonist cycles & $18(17.3 \%)$ & $269(12.8 \%)$ & 0.2 \\
\hline hCG day estradiol & $1760 \pm 1057$ & $2227 \pm 1241$ & $<0.001^{*}$ \\
\hline hCG day endometrial thickness & $9.4 \pm 2.1$ & $10.5 \pm 2.1$ & $113(5.1 \%)$ \\
\hline Failed to induce follicular growth & $13(12.4 \%)$ & $11.2 \pm 6.6$ & $0.001 *$ \\
\hline Number of oocytes retrieved & $10.6 \pm 6$ & $9.2 \pm 5.6$ & 0.4 \\
\hline Number of MII oocytes & $8.2 \pm 5.1$ & $92.6 \pm 20.5$ & 0.08 \\
Cleavage rate & $95.2 \pm 16.7$ & $67.2 \pm 25.7$ & 0.2 \\
\hline Fertilization rate & $63.7 \pm 25.8$ & $2.5 \pm 1$ & 0.2 \\
Grade 1 and 2 embryo count & $2.4 \pm 0.9$ & 0.3
\end{tabular}

*Statistically significant $(\mathrm{p}<0.05)$, independent samples t-test

FSH: Follicle-stimulating hormone, hCG: Human chorionic gonadotropin, MII: Metaphase II 
Table 4. Cycle cancellation and pregnancy outcome

\begin{tabular}{|llll}
\hline Variable & Subclinical hypothyroidism $(\mathrm{n}=105)$ & Euthyroid controls $(\mathrm{n}=2231)$ & $\mathrm{p}$ \\
\hline Cycle cancellation rate & $17(16.1 \%)$ & $257(11.5 \%)$ & 0.1 \\
\hline No dominant follicle & $13(12.4 \%)$ & $113(5.1 \%)$ & $0.001^{*}$ \\
\hline Risk of ovarian hyperstimulation syndrome & 0 & $16(0.7 \%)$ & 0.4 \\
\hline Fertilization failure & $2(1.9 \%)$ & $83(3.7 \%)$ & 0.3 \\
\hline Others** & $2(1.9 \%)$ & $45(2 \%)$ & 0.9 \\
\hline Pregnancy per embryo transfer cycle & $17(19.3 \%)$ & $657(33.3 \%)$ & $0.006^{*}$ \\
Clinical pregnancy rate & $14(15.9 \%)$ & $574(29.1 \%)$ & $0.007^{*}$ \\
\hline Take-home baby rate & $9(10.2 \%)$ & $436(22.1 \%)$
\end{tabular}

* Statistically significant $(\mathrm{p}<0.05)$, chi-square test

**Others include failed to retrieve metaphase II oocyte, failed to retrieve sperm and failed cleavage

Table 5. Outcome of patients with subclinical hypothyroidism with and without hyperprolactinemia (>30)

\begin{tabular}{|c|c|c|c|}
\hline Outcome & Subclinical hypothyroidism $(\mathrm{n}=57)$ & $\begin{array}{l}\text { Subclinical hypothyroidism with } \\
\text { hyperprolactinemia }(n=48)\end{array}$ & $\mathrm{p}$ \\
\hline Total FSH used & $3039 \pm 1462$ & $2961 \pm 1233$ & 0.2 \\
\hline Number of oocytes retrieved & $10.6 \pm 6$ & $11.2 \pm 6.6$ & 0.4 \\
\hline Fertilization rate & $63.7 \pm 25.8$ & $67.2 \pm 25.7$ & 0.2 \\
\hline Grade 1 and 2 embryo count & $2.4 \pm 0.9$ & $2.5 \pm 1$ & 0.3 \\
\hline Number of oocytes retrieved & $10.6 \pm 6$ & $11.2 \pm 6.6$ & 0.4 \\
\hline Take-home baby rate & $6(12.2 \%)$ & $3(7.7 \%)$ & 0.4 \\
\hline
\end{tabular}

FSH: Follicle-stimulating hormone, hCG: Human chorionic gonadotropin, MII: Metaphase II

Table 6. Intracytoplasmic sperm injection outcomes according to thyroid-stimulating hormone values in patients with subclinical hypothyroidism

\begin{tabular}{|c|c|c|c|}
\hline Outcome & $\begin{array}{l}\text { Subclinical hypothyroidism TSH }<10 \\
(\mathrm{n}=93)\end{array}$ & $\begin{array}{l}\text { Subclinical hypothyroidism } \text { TSH } \geq 10 \\
(\mathrm{n}=12)\end{array}$ & $\mathrm{p}$ \\
\hline Total FSH used & $2858 \pm 1124$ & $4127 \pm 2299$ & 0.1 \\
\hline hCG day estradiol & $1878 \pm 1048$ & $866 \pm 633$ & $0.01 *$ \\
\hline Cycle cancellation rate & $11(11.8 \%)$ & $6(50 \%)$ & $0.001 * *$ \\
\hline Pregnancy per embryo transfer cycle & $14 / 85$ & $3 / 6$ & \\
\hline Clinical pregnancy rate & $12 / 85$ & $2 / 6$ & \\
\hline Take-home baby rate & $7 / 85$ & $2 / 6$ & \\
\hline
\end{tabular}

*Statistically significant $(\mathrm{p}<0.05)$, Mann-Whitney test

** Statistically significant $(\mathrm{p}<0.05)$, chi-square test

FSH: Follicle-stimulating hormone, hCG: Human chorionic gonadotropin, TSH: thyroid-stimulating hormone 


\section{Discussion}

Experimental studies have demonstrated an interaction of thyroid hormones with ovarian function, and clinical studies have also reported negative effects of thyroid hormonal excess or defects with overt clinical signs and symptoms ${ }^{(1-5)}$. However, diagnosis of subclinical hypothyroidism depends on laboratory analysis rather than clinical symptoms; therefore, its possible effects on fertility status and pregnancy rates with ART need to be clarified. To achieve this aim, previous studies reported contrary results including improved pregnancy rates with $\mathrm{T} 4$ treatment or no change in pregnancy rates with $\mathrm{T} 4$ treatment, even in infertile patients with overt hypothyroidism ${ }^{(8,9,11-14)}$. In this multicenter retrospective study, the TSH cut-off value was set as $4.5 \mathrm{mIU} / \mathrm{L}$ for the diagnosis of subclinical hypothyroidism, as suggested previously by the consensus of the American Endocrine Society, the American Thyroid Association, and the American Association of Clinical Endocrinologists ${ }^{(6)}$.

However, in a relatively recent study, two different cut-off values $(2.5 \mathrm{mIU} / \mathrm{L}$ vs. $4.5 \mathrm{mIU} / \mathrm{L})$ values were compared in terms of rates of clinical pregnancy, delivery or miscarriage in a large, retrospective cohort study of patients undergoing their first in vitro fertilization (IVF) cycle ${ }^{(11)}$. No statistical differences were found between the groups and it was suggested that lowering the TSH cut-off value would increase the diagnosis rate of subclinical hypothyroidism five-fold ${ }^{(11)}$. In our study, however, when we compared groups with TSH values of 4.5 to 9.9 or $\geq 10 \mathrm{mIU} / \mathrm{L}$, we found a significant higher rate of cycle cancellations in patients with TSH $\geq 10 \mathrm{mIU} / \mathrm{L}$. Nevertheless, the clinical pregnancy rates and take-home baby rate did not differ, in a similar manner with the previous study, which compared TSH values of 2.5 vs. $4.5 \mathrm{mIU} / \mathrm{L}^{(11)}$. In this present study, we used an ICSI population to determine the possible effects of subclinical hypothyroidism. Previously, it was shown that overt hypothyroidism was related with a decreased chance of achieving pregnancy following IVF, even with appropriate treatment ${ }^{(5)}$. In another study that determined outcomes of controlled ovarian hyper-stimulation in women with thyroid autoimmune disease, oocyte pickup and embryo transfer, the performance of recombinant-FSH was significantly poorer in patients with thyroid autoimmune disease ${ }^{(12)}$. When TSH values with a cut-off value of $2.5 \mathrm{IU} / \mathrm{L}$ were compared, significantly higher serum E2 concentrations was determined in those with $<2.5 \mathrm{IU} / \mathrm{L}^{(12)}$. In our study, we found a similar significant difference when comparing TSH values of 4.59.9 vs. 10 or more IU/L. In our study, the rate of subclinical hypothyroidism was 5\%; however, in a previous study, it was reported as high as $13.9 \%$, which was a significantly higher rate compared with fertile patients $(3.9 \%)^{(13)}$. In the present study, the euthyroid group had an incidental higher frequency of endometriosis, anovulation, and unexplained infertility, all of which are expected to decrease success rates in ICSI cycles by themselves. However, despite this, we found a significantly lower clinical pregnancy and take-home baby rate in the study group compared with the control group.
The findings of the current study and some other previous observations as mentioned above need to be verified with further epidemiologic and experimental studies. In a study that compared laboratory results of blood samples drawn every 10 minutes during a 24-h period for pulse analysis of $\mathrm{LH}, \mathrm{TSH}$, and prolactin, no difference was found between euthyroid hypothyroid patients or those with subclinical hypothyroidism ${ }^{(14)}$. It was concluded that corpus luteum insufficiency in female infertility could not be explained by subclinical hypothyroidism and thus should not be treated with L-thyroxin for fertility reasons ${ }^{(14)}$. However, another study concerning hypothyroidism in IVF cycles concluded that high circulating estradiol during superovulation for IVF increased the binding of thyroxin to thyroxin-binding globulin, resulting in relative hypothyroidism during a super-ovulation cycle in women taking thyroxin replacement therapy ${ }^{(15)}$.

\section{Study Limitations}

Major limitation of this study is that it depends on retrospective data analyses, which necessitates to be confirmed by further well designed prospective clinical study regarding effects of subclinical hypothyroidism on ICSI cycles.

\section{Conclusion}

In conclusion, both the clinical pregnancy and take-home baby rate are lower in women with subclinical hypothyroidism at the time of ICSI cycle, regardless of T4 treatment.

\section{Ethics}

Ethics Committee Approval: Retrospective study.

Informed Consent: Retrospective study.

Peer-review: External and internal peer-reviewed.

\section{Authorship Contributions}

Surgical and Medical Practices: E.Ç., R.N.E., D.C.Ö., B.K., S.Ç., K.S., Concept: E.Ç., R.N.E., D.C.Ö., B.K., S.Ç., K.S., Design: E.Ç., R.N.E., D.C.Ö., B.K., S.Ç., K.S., Data Collection or Processing: E.Ç., R.N.E., D.C.Ö., B.K., S.Ç., K.S., Analysis or Interpretation: E.Ç., R.N.E., Literature Search: E.Ç., R.N.E., Writing: E.Ç., R.N.E.

Conflict of Interest: No conflict of interest was declared by the authors.

Financial Disclosure: The authors declared that this study received no financial support.

\section{References}

1. Maruo T, Hayashi M, Matsuo H, Yamamoto T, Okada H, Mochizuki $\mathrm{M}$. The role of thyroid hormone as a biological amplifier of the actions of follicle-stimulating hormone in the functional differentiation of cultured porcine granulosa cells. Endocrinology 1987;121:1233-41.

2. Goldman S, Dirnfeld M, Abramovici H, Kraiem Z. Triiodothyronine and folliclestimulating hormone, alone and additively together, stimulate production of the tissue inhibitor of etalloproteinases- 1 in cultured human luteinized granulosa cells. J Clin Endocrinol Metab 1997;82:1869-73.

3. Spicer LJ, Alonso J, Chamberlain CS. Effects of thyroid hormones on bovine granulosa and thecal cell function in vitro: dependence on insulin and gonadotropins. J Dairy Sci 2001;84:1069-76. 
4. Gerhard I, Becker T, Eggert-Kruse W, Klinga K, Runnebaum B. Thyroid and ovarian function in infertile women. Hum Reprod 1991;6:338-45.

5. Scoccia B, Demir H, Kang Y, Fierro MA, Winston NJ. In vitro fertilization pregnancy rates in levothyroxine-treated women with hypothyroidism compared to women without thyroid dysfunction disorders. Thyroid 2012;22:631-6.

6. Surks MI, Ortiz E, Daniels GH, Sawin CT, Col NF, Cobin RH, et al. Subclinical thyroid disease: scientific review and guidelines for diagnosis and management. JAMA 2004;291:228-38.

7. Reid SM, Middleton P, Cossich MC, Crowther CA, Bain E. Interventions for clinical and subclinical hypothyroidism prepregnancy and during pregnancy. Cochrane Database Syst Rev 2013; CD007752.

8. Kim CH, Ahn JW, Kang SP, Kim SH, Chae HD, Kang BM. Effect of levothyroxine treatment on in vitro fertilization and pregnancy outcome in infertile women with subclinical hypothyroidism undergoing in vitro fertilization/intracytoplasmic sperm injection. Fertil Steril 2011;95:1650-4.

9. Busnelli A, Somigliana E, Benaglia L, Leonardi M, Ragni G, Fedele L. In vitro fertilization outcomes in treated hypothyroidism. Thyroid 2013;23:1319-25.
10. Sharma LK, Sharma N, Gadpayle AK, Dutta D. Prevalence and predictors of hyperprolactinemia in subclinical hypothyroidism. Eur J Intern Med 2016;35:106-10.

11. Reh A, Grifo J, Danoff A. What is a normal thyroid-stimulating hormone (TSH) level? Effects of stricter TSH thresholds on pregnancy outcomes after in vitro fertilization. Fertil Steril 2010;94:2920-2.

12. Magri F, Capelli V, Gaiti M, Brambilla E, Montesion L, Rotondi M, et al. Impaired outcome of controlled ovarian hyperstimulation in women with thyroid autoimmune disease. Thyroid 2013;23:1312-8.

13. Abalovich M, Mitelberg L, Allami C, Gutierrez S, Alcaraz G, Otero $\mathrm{P}$, et al. Subclinical hypothyroidism and thyroid autoimmunity in women with infertility. Gynecol Endocrinol 2007;23:279-83.

14. Bals-Pratsch M, De Geyter C, Müller T, Frieling U, Lerchl A, Pirke $\mathrm{KM}$, et al. Episodic variations of prolactin, thyroid-stimulating hormone, luteinizing hormone, melatonin and cortisol in infertile women with subclinical hypothyroidism. Hum Reprod 1997; 12:896-904.

15. Stuckey BG, Yeap D, Turner SR. Thyroxine replacement during superovulation for in vitro fertilization: a potential gap in management? Fertil Steril 2010;93:2414.e1-3. 